\title{
The impact of the shadow economy on the country's financial security
}

\author{
Oleg Meleshko ${ }^{1}$, Nataliia Prokopenko ${ }^{1}$, and Olena Gudz ${ }^{2, *}$ \\ ${ }^{1}$ European University, 02000, Vernadskogo av., Ukraine \\ ${ }^{2}$ State University of Telecommunications 02000 , Solomianskast., Ukraine
}

\begin{abstract}
The article is devoted to determining the features of the shadow economy's impact on financial security. For this purpose the following are carried out: generalization of calculation indicators in the shadow economy; influence assessment level of the shadow economy on the volume of gross domestic product (further-GDP); based matrix paired correlation coefficients integral indicator of financial security and factors of shadow economy by various methods; conducted surveillance on the dynamics of the integral index of financial security and the level of the shadow economy, calculated using monetary means and integral measure of financial security of cash in UAH and the dollar; investigated the interconnection statistical indicators and indicators of financial security dynamics of cash in the economy; evaluated the safety performance of non-banking financial market and the volume of cash in dollar terms in dynamics; Then a matrix construction paired correlation coefficients tax rate component of financial security and the coefficients of the shadow economy, estimated by different methodological approaches; monitored security tax rate and share of lossmaking enterprises and statistical significance is estimated regression equation pair of security and tax number of unprofitable enterprises.
\end{abstract}

\section{Introduction}

A prerequisite for determining the peculiarities of the shadow economy on financial security is its negative impact on the most basic economic processes: development and income distribution, trade, investment and economic development. Considering it is quite obvious is the need for a thorough study of this problem through the prism of its impact on the performance of financial security. At the same time, the works of scientists and practitioners [1-8] highlight the general approaches to determining the impact of the shadow economy on the financial security of the country, and given the rapid changes in economic processes, both in the world and in the country, this problem requires further research. In practice, this aspect of the study is limited Methodological Recommendations calculation of the shadow economy, approved by the Ministry of Economy of Ukraine 18.02.2009 № (now the Ministry of Economy, Trade and Agriculture of Ukraine) [5]. Given the turbulence of the domestic and global economy, this is not enough. Therefore, the purpose of this article is to reveal the algorithm for determining the impact of the shadow economy on various aspects

\footnotetext{
* Corresponding author: yahodzinskyi.serhii@gmail.com
} 
of national financial security. Thus, a subgroup is created for the development of regulations that determine the characteristics of the impact of the shadow economy on various methods and in terms of components of financial security. In our opinion, the algorithm for diagnosing the impact of the shadow economy on financial security should include the following components of financial security: budget, debt, currency, monetary, banking, tax, and security of the non-banking sector of the financial market.

\section{Materials and Methods}

These components of financial security are interrelated. Thus, in order to de-shadow the economic sector in the financial security system, it is impossible to consider and assess the impact of one or another component of financial security. Thus, to assess the impact of the shadow economy on the fiscal sector, it is necessary to analyze the level of influence of factors that indirectly affect the performance of the fiscal sphere. Accordingly, we are going to try to determine the basic components of the algorithm for shaping the impact of the shadow sector at the level of financial security of the country based on the study of all factors influencing the financial and economic development of the country using the method of enterprise losses; by the method of "population expenditure - retail trade and services"; by the electric method; using the financial method, which will allow for a comprehensive analysis and effective management decisions in the formation of financial policy in terms of financial security of the country.

\section{Value-willed stage}

The largest part of the shadow economy is formed in the tax sphere, in the banking and nonbanking sectors of the financial market. The crisis situation in the country's economy affects the formation of power structures in society, efforts to develop and implement measures to de-shadow the financial sector in order to strengthen financial security. This requires balanced approaches to reassessing the trends of the shadow economy in Ukraine at the state level. The latter is carried out on the basis of the developed Methodical recommendations for calculating the level of the shadow economy, approved by the Order of the Ministry of Economy of Ukraine 18.02.2009 № 123 [9]. As of 2020, the Department for Economic Security, De-Shading of the Economy and Statistics of the Department of Strategic Planning and Macroeconomic Forecasting of the Ministry of Economy of Ukraine calculates the following indicators of the shadow economy (Table 1):

1) The level of the shadow economy by the method of unprofitable enterprises, $\%$ of official GDP;

2) The level of the shadow economy by the method of "population expenditures - retail trade and services", \% of official GDP;

3) The level of the shadow economy by the electric method, \% of official GDP;

4) The level of the shadow economy using the financial method, \% of official GDP. 
Table 1. The level of the shadow economy, calculated with different methods, $\%$ of the official volume GDP, 2010-2019 [10].

\begin{tabular}{|c|c|c|c|c|c|c|c|c|c|c|}
\hline Indicator & 응 & $\overline{\bar{N}}$ & $\stackrel{\mathfrak{N}}{\stackrel{\mathrm{N}}{ }}$ & 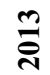 & 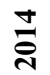 & $\stackrel{n}{\stackrel{\rho}{\rho}}$ & 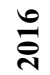 & $\frac{\bar{\nu}}{\bar{\nu}}$ & $\stackrel{\infty}{\vec{N}}$ & $\stackrel{\overrightarrow{\mathcal{N}}}{\mathrm{i}}$ \\
\hline $\begin{array}{l}\text { The level of the } \\
\text { shadow } \\
\text { economy by the } \\
\text { method of } \\
\text { unprofitable } \\
\text { enterprises }\end{array}$ & 34 & 29 & 31 & 31 & 35 & 30 & 25 & 25 & 23 & 20 \\
\hline $\begin{array}{l}\text { The level of the } \\
\text { shadow } \\
\text { economy by the } \\
\text { method of } \\
\text { "population } \\
\text { expenditures - } \\
\text { retail trade and } \\
\text { services" }\end{array}$ & 30 & 43 & 40 & 40 & 44 & 44 & 38 & 38 & 33 & 30 \\
\hline $\begin{array}{l}\text { The level of the } \\
\text { shadow } \\
\text { economy by the } \\
\text { electric method }\end{array}$ & 36 & 28 & 28 & 30 & 38 & 35 & 31 & 29 & 27 & 26 \\
\hline $\begin{array}{l}\text { The level of the } \\
\text { shadow } \\
\text { economy using } \\
\text { the financial } \\
\text { method }\end{array}$ & 38 & 34 & 30 & 29 & 33 & 33 & 33 & 31 & 32 & 30 \\
\hline
\end{tabular}

\section{Conceptual stage}

The basis of the conceptual phase of assessing the impact of the shadow economy to financial security is the idea of determining the relationships of indicators of the shadow economy, estimated by different methods, with a combined ratio of financial security, as well as indicators of its formation (fiscal, monetary, debt, currency, banking security, as well as the security of the non-banking sector). At the initial stage of the study, a correlation analysis of the relationship between the integrated financial security ratio was performed $(y)$ with the above indicators of the level of the shadow economy $\left(\mathrm{x}_{j}\right)$, where:

$\mathrm{x}_{1}$ - the level of the shadow economy by the method of unprofitable enterprises;

$\mathrm{x}_{2}$ - the level of the shadow economy by the method of "population expenditure - retail trade and services";

$\mathrm{x}_{3}$ - the level of the shadow economy by the electric method;

$\mathrm{x}_{4}$ - the level of the shadow economy using the financial method.

The multiple correlation coefficient, $R$ is 0.7526 , which indicates a strong relationship between the resultant trait $Y$ and factors $X_{i}$.

The matrix of paired correlation coefficients is given in table. 2 . 
Table 2. Matrix of paired correlation coefficients of the integrated indicator of financial security and coefficients of the level of the shadow economy, calculated by different methodological approaches, $\mathrm{R}$ (author's calculation).

\begin{tabular}{|c|c|c|c|c|c|}
\hline- & $\mathbf{y}$ & $\boldsymbol{x}_{\mathbf{1}}$ & $\boldsymbol{x}_{\mathbf{2}}$ & $\boldsymbol{x}_{\mathbf{3}}$ & $\boldsymbol{x}_{\mathbf{4}}$ \\
\hline $\mathbf{y}$ & 1 & 0.1822 & 0.2157 & -0.2034 & $\mathbf{- 0 . 5 3 6 9}$ \\
\hline $\boldsymbol{x}_{\mathbf{1}}$ & 0.1822 & 1 & 0.4765 & 0.7643 & 0.4152 \\
\hline $\boldsymbol{x}_{\mathbf{2}}$ & 0.2157 & 0.4765 & 1 & 0.3165 & -0.1606 \\
\hline $\boldsymbol{x}_{\mathbf{3}}$ & -0.2034 & 0.7643 & 0.3165 & 1 & 0.5891 \\
\hline $\boldsymbol{x}_{\mathbf{4}}$ & $\mathbf{- 0 . 5 3 6 9}$ & 0.4152 & -0.1606 & 0.5891 & 1 \\
\hline
\end{tabular}

From the correlation analysis it follows that the greatest closeness of the connection $(R=$ $-0,5369)$ observed in the inverse interdependence of the integrated indicator of financial security and the level of the shadow economy, calculated using the financial method.

The financial approach is based on the use of P. Gutman's method, which takes into account the relationship between cash and bank deposits (for the first time such a technique to explain the dynamics of the shadow economy was proposed by P. Kagan in 1958, explaining the growing demand for cash by illegal transactions "black market" USA). The relationship between GDP and demand for cash is determined by the formula:

$$
\mathrm{T}_{m \Gamma_{t}}=\frac{1-f_{t}}{f_{t-1}}
$$

where $f_{t}$ - an indicator of the ratio of the volume of deposits to the financial aggregate in the period under analysis;

$f_{t-1}-$ an indicator of the ratio of deposits to the financial aggregate in the same period last year.

The ratio of the volume of deposits to the financial aggregate M2 $(f)$ in these periods is calculated by the following formula:

$$
f=\frac{\frac{D}{M 2}}{\frac{D t_{0}}{M 2}}=\frac{\frac{M 2-M 0}{M 2}}{\frac{M 2 t_{0}-M 0 t_{0}}{M 2 t_{0}}},
$$

where $M 2$ - money supply in the corresponding period (million UAH);

$D$ - bank deposits in the corresponding period (million UAH);

$M 0$ - money outside banks in the relevant period (million UAH);

$t_{0}$ - the base period for which 1991 was adopted.

Note that according to the methodological approach developed by the Ministry of Economy, when calculating the level of the shadow economy by the financial method, it is assumed that the base is a "conditional" year, in which the ratio of deposits to the financial aggregate $\mathrm{M}_{2}\left(f_{0}=\frac{M 2-M 0}{M 2}\right)$ is 0,95 . The result of the ratio $\mathrm{f}_{0}$ was determined by the method of averaging and analogies based on the experience of countries (Belgium, Great Britain, Denmark, Sweden), the result of the ration in which $\mathrm{f}_{0}$ is high, and the level of the shadow economy among the countries of the world, according to IMF expert Friedrich Schneider, is insignificant $(<20 \%)$. In this case, any increase in cash is evidence of the formation of potential opportunities to increase the level of the shadow economy [10]. 
In view of the above, to study the impact of increasing cash in the economy on the level of financial security, a regression analysis of the relationship between these two factors.

As a result of the analysis the following statistical indicators are defined:

- $\quad$ Linear correlation coefficient:

$$
r_{x y}=\frac{\overline{x \cdot y}-\bar{x} \cdot \bar{y}}{S_{(x)} \cdot S_{(y)}}=\frac{127104.7-277722.947 \cdot 0.459}{68195.671 \cdot 0.0423}=-0.0926
$$

- Coefficient of elasticity:

$$
E=\frac{\partial y}{\partial x} \frac{x}{y}=b \frac{\bar{x}}{\bar{y}}=-0.0348
$$

which values indicate the lack of interdependence between the dynamics of cash in the UAH equivalent and the performance indicator - the coefficient of financial security.

Subsequent studies have shown that the interdependence between the financial security ratio and the dynamics of cash in dollar terms is much stronger than with a similar figure in UAH equivalent.

In particular, as a result of correlation and regression analysis obtained the following regression equation pair: $y=0,00421 x+0,3776$

The sample linear correlation coefficient is:

$$
r_{x y}=\frac{\overline{x \cdot y}-\bar{x} \cdot \bar{y}}{S_{(x)} S_{(y)}}=\frac{8.982-19.221 \cdot 0.459}{6.288 \cdot 0.0423}=0.627
$$

indicating that there is a strong relationship between the financial security ratio and the dynamics of cash in dollar terms. At the same time, the connection between the features turned out to be direct, which contradicts the working hypothesis about the negative impact of the growth of cash in the economy on the financial security of the country.

To establish the feasibility of using the constructed regression model, we calculate the statistical significance of the correlation coefficient.

To do this, we put forward two hypotheses:

H0: $r_{x y}=0$, there is no linear relationship between variables;

$\mathrm{H} 1: r_{x y} \neq 0$, there is a linear interdependence between variables.

According to the Student's table at the level of significance $\alpha=0.05$ and degrees of freedom $\kappa=8: t_{\text {critic }}(n-m-1 ; \alpha / 2)=t_{\text {critic }}(8 ; 0,025)=2,752$ where $m=1-$ the number of declared variables.

$$
t_{n a b l}=0.627 \frac{\sqrt{8}}{\sqrt{1-0.627^{2}}}=2.274
$$

Whereas $\left|t_{\text {appr }}\right|<t_{\text {critic }}$, then the hypothesis of equality of zero correlation coefficients is accepted. In other words, the correlation coefficient has no statistical significance, and therefore cannot be used to substantiate conclusions about the impact of the dynamics of cash in the economy on the financial security of the country.

To further test the working hypothesis on the impact of cash growth on financial security indicators, a correlation analysis of the impact of cash dynamics on indicators of monetary, budgetary, debt, currency, banking security and security of non-banking financial market. The results of the analysis are given in Table 3 . 
Table 3. Statistical indicators of the interconnection in financial security indicators $\left(y_{i}\right)$ and the dynamics of cash in the economy (x) (authors' calculation).

\begin{tabular}{|c|c|c|c|c|}
\hline № & $\begin{array}{c}\text { Financial } \\
\text { security } \\
\text { indicator, } \\
\text { yi }\end{array}$ & $\begin{array}{l}\text { Linear correlation } \\
\text { coefficient } \\
r_{x y}=\frac{\bar{x} \cdot \bar{y}-\bar{x} \cdot \bar{y}}{S_{(x)} S_{(y)}}\end{array}$ & $\begin{array}{c}\text { Significance of the } \\
\text { correlation coefficient } \\
t_{n a b l}=r_{x y} \frac{\sqrt{n-2}}{\sqrt{1-r_{x y}^{2}}} \\
t_{c r i t i c}(n-m-1 ;(\alpha / 2) \\
=t_{c r i t i c}(8 ; 0.025)=2.752\end{array}$ & $\begin{array}{l}\text { Coefficient of } \\
\text { elasticity } \\
E=\frac{\partial y}{\partial x} \frac{x}{y}=b \frac{\bar{x}}{\bar{y}}\end{array}$ \\
\hline 1 & $\begin{array}{l}\text { Budget } \\
\text { security }\end{array}$ & $\begin{array}{c}\frac{11.575-19.221 \cdot 0.589}{6.288 \cdot 0.115}=0.363 \\
\text { connection }\end{array}$ & $\begin{array}{c}0,307 \frac{\sqrt{8}}{\sqrt{1-0,307^{2}}}=0,911 \\
\left|t_{\text {appr }}\right|<t_{\text {critic. }}-\text { the } \\
\text { coefficient is not } \\
\text { significant }\end{array}$ & $\begin{array}{l}-0.00321 \frac{19.221}{0.474}=-0.13 \\
\text { the effect of } X \text { on } Y \text { is } \\
\text { not significant }\end{array}$ \\
\hline 2 & $\begin{array}{c}\text { Debt } \\
\text { security }\end{array}$ & $\frac{5.167-19.221 \cdot 0.244}{6.288 \cdot 0.0837}=0.9$ & $\begin{array}{c}0.903 \frac{\sqrt{8}}{\sqrt{1-0.903^{2}}}=5.929 \\
\left|t_{\text {appr }}\right|<t_{\text {critic. }}-\text { the } \\
\text { coefficient is significant }\end{array}$ & $\begin{array}{c}0.012 \frac{19.221}{0.244}=0.946 \\
\text { the effect of } X \text { on } Y \text { is } \\
\text { not significant }\end{array}$ \\
\hline 3 & $\begin{array}{c}\text { Financial } \\
\text { security }\end{array}$ & $\frac{11.575-19.221 \cdot 0.589}{6.288 \cdot 0.115}=0.363$ & $\begin{array}{l}0.363 \frac{\sqrt{8}}{\sqrt{1-0.363^{2}}}=1.103 \\
\left|t_{\text {appr }}\right|<t_{\text {critic }}-\text { the } \\
\text { coefficient is not } \\
\text { significant }\end{array}$ & $\begin{array}{c}0.00666 \frac{19.221}{0.589}=0.218 \\
\text { the effect of } X \text { on } Y \text { is } \\
\text { not significant }\end{array}$ \\
\hline 4 & $\begin{array}{c}\text { Monetary } \\
\text { security }\end{array}$ & $\frac{8.99-19.221 \cdot 0.474}{6.288 \cdot 0.0659}=0.307$ & $\begin{array}{l}0.307 \frac{\sqrt{8}}{\sqrt{1-0.307^{2}}}=0.911 \\
\left|t_{\text {appr }}\right|<t_{\text {critic }}-\text { the } \\
\text { coefficient is not } \\
\text { significant }\end{array}$ & $\begin{array}{c}-0.00321 \frac{19.221}{0.474}=-0.13 \\
\text { the effect of } X \text { on } Y \text { is } \\
\text { not significant }\end{array}$ \\
\hline 5 & $\begin{array}{l}\text { Banking } \\
\text { security }\end{array}$ & $\frac{7.989-19.221 \cdot 0.4}{6.288 \cdot 0.0991}=0.476$ & $\begin{array}{l}0.476 \frac{\sqrt{8}}{\sqrt{1-0.476^{2}}}=1.53 \\
\left|t_{\text {appr }}\right|<t_{\text {critic }}-\text { the } \\
\text { coefficient is not } \\
\text { significant }\end{array}$ & $\begin{array}{l}0.0075 \frac{19.221}{0.4}=0.36 \\
\text { the effect of } X \text { on } Y \text { is } \\
\text { not significant }\end{array}$ \\
\hline 6 & $\begin{array}{l}\text { Security } \\
\text { of the } \\
\text { non- } \\
\text { banking } \\
\text { financial } \\
\text { market }\end{array}$ & $\frac{8.331-19.221 \cdot 0.416}{6.288 \cdot 0.0706}=0.754$ & $\begin{array}{c}0.754 \frac{\sqrt{8}}{\sqrt{1-0.754^{2}}}=3.25 \\
\left|t_{\text {appr }}\right|<t_{\text {critic }}-\text { the } \\
\text { coefficient is significant }\end{array}$ & $\begin{array}{c}0.00848 \frac{19.221}{0.416}=0.392 \\
\text { the effect of } X \text { on } Y \text { is } \\
\text { not significant }\end{array}$ \\
\hline
\end{tabular}

Based on the results of the analysis, the following conclusions can be drawn that the nature of the impact of cash growth on financial security indicators differs: in five of the six pair dependences of factor and performance there is a direct relationship, which, as noted above, contradicts hypotheses about the factors influencing the shadow economy on financial security. At the same time, only two correlation coefficients were significant, namely: the correlation coefficient of debt security and the increase in cash $\left(r_{x y}=0.903\right)$ and the correlation coefficient of the security of the non-banking financial market and the growth of cash $\left(r_{x y}=0.754\right)$. Since in both cases the closeness of the connection is strong, there is every reason to conduct a further regression analysis of these interconnections.

The dependence of debt security and the increase in cash can be represented as a pairwise regression equation: $y=0.01202 x+00131$, that is, an increase in cash by $\$ 1$ million. US means an increase in debt security on average by 0,012 units.

Selective variances:

$$
S^{2}(x)=\frac{\sum x_{t}^{2}}{n}-\bar{x}^{2}=\frac{4089.98}{10}-19.221^{2}=39.53
$$




$$
S^{2}(y)=\frac{\sum y_{t}^{2}}{n}-\bar{y}^{2}=\frac{0.67}{10}-0.244^{2}=0.00701
$$

The standard deviation:

$$
\begin{gathered}
S(x)=\sqrt{S^{2}(x)}=\sqrt{39.53}=6.288 \\
S(y)=\sqrt{S^{2}(y)}=\sqrt{0.00701}=0.0837
\end{gathered}
$$

Accordingly, the beta coefficient is:

$$
\beta_{j}=b_{j} \frac{S(x)}{S(y)}=0.012 \frac{6.288}{0.0837}=0.903
$$

that is, an increase in the amount of cash by the standard deviation $S_{x}$ will increase the average level of debt security by $90.3 \%$ of the standard deviation $S_{y}$.

Coefficient of determination $R^{2}=0.8146$, that is, in $81.46 \%$ of cases, a change in $\mathrm{x}$ leads to a change in $\mathrm{y}$. Therefore, the accuracy of the regression equation is high.

F-statistics.

$$
\begin{gathered}
F=\frac{R^{2}}{1-R^{2}} \frac{n-m-1}{m} \\
F=\frac{0.8146}{1-0.8146} \frac{10-1-1}{1}=35.148
\end{gathered}
$$

At degrees of freedom $k_{1}=1, k_{2}=8, F_{\text {tabular }}=5.32$.

Whereas $F>F_{\text {tabular }}$, then the coefficient of determination is statistically significant (the regression equation is statistically reliable).

The dependence of the security of the non-banking financial market and the increase in cash can be represented as a pairwise regression equation: $y=0.00848 x+0.2531$, that is, an increase in cash by $\$ 1$ million. US means an increase in debt security on average by 0,00848 units.

Selective variances:

$$
\begin{aligned}
& S^{2}(x)=\frac{\sum x_{t}^{2}}{n}-\bar{x}^{2}=\frac{4089.98}{10}-19.221^{2}=39.53 \\
& S^{2}(y)=\frac{\sum y_{t}^{2}}{n}-\bar{y}^{2}=\frac{1.78}{10}-0.416^{2}=0.00499
\end{aligned}
$$

The standard deviation:

$$
\begin{gathered}
S(x)=\sqrt{S^{2}(x)}=\sqrt{39.53}=6.288 \\
S(y)=\sqrt{S^{2}(y)}=\sqrt{0.00499}=0.0706
\end{gathered}
$$

Accordingly, the beta coefficient is:

$$
\beta_{j}=b_{j} \frac{S(x)}{S(y)}=0.00848 \frac{6.288}{0.0706}=0.754
$$

that is, an increase in the amount of cash by the standard deviation $S_{x}$ will increase the average level of debt security by $75.4 \%$ of the standard deviation $S_{y}$.

Coefficient of determination $R^{2}=0.569$, that is, in $56.9 \%$ of cases, a change in x leads to a change in $\mathrm{y}$. Therefore, the accuracy of the regression equation is high.

F-statistics:

$$
F=\frac{R^{2}}{1-R^{2}} \frac{n-m-1}{m}
$$




$$
F=\frac{0.569}{1-0.569} \frac{10-1-1}{1}=10.564
$$

At degrees of freedom $k_{1}=1 . k_{2}=8, F_{\text {tabular }}=5.32$.

Whereas $F>F_{\text {tabular. }}$, then the coefficient of determination is statistically significant (the regression equation is statistically reliable).

Returning to the results of correlation analysis (Table 3), we note that the hypothesis of the negative impact of cash growth on financial security confirms the interconnection between cash and financial security. Moderate feedback $\left(r_{x y}=-0.307\right)$ is represented by the pairwise regression equation: $y=-0.00321 x+0.536$. Possible economic interpretation of the models increases in cash of 1 million dollars US leads to a decrease in monetary security on average by 0,00321 units.

At the same time, it was found that in the studied situation only $9.4 \%$ of the total variability $Y$ is determined by the change $X$, the statistical significance of the model is critically low, and therefore its use to form scientific conclusions is considered impractical.

According to recent studies, the greatest impact on the shadow economy has an increase in the tax burden and the amount of social security contributions (Table 4) [8]. Therefore, an important aspect of the study is to assess the close relationship between the shadow economy and the tax rate.

Table 4. The main reasons for the growth of the shadow economy in developed countries [8].

\begin{tabular}{|c|c|}
\hline $\begin{array}{c}\text { Factors contributing to the growth of the } \\
\text { shadow economy }\end{array}$ & Degree of influence \\
\hline $\begin{array}{c}\text { Increase in the tax burden and the amount of social } \\
\text { security contributions }\end{array}$ & $45-52 \%$ \\
\hline Quality of state institutions & $12-17 \%$ \\
\hline Transfers & $7-9 \%$ \\
\hline Labor market regulation & $7-9 \%$ \\
\hline Public services & $7-9 \%$ \\
\hline Taxpayer morale & $22-25 \%$ \\
\hline Influence of all factors & $78-96 \%$ \\
\hline
\end{tabular}

The peculiarities of Ukrainian realities come down to the fact that domestic business suffers not only from the tax burden, but also from administrative pressure and nontransparent "rules of the game" in the tax sphere. In view of this problem of the influence of the shadow economy on financial security should be considered in the light of the tax component integral index of financial security [11, 44-47].

Built correlation matrix (tab. 5) shows that the impact of the shadow economy on the tax component of financial security is more significant, and in close connection with two effective features are the coefficient of the shadow economy: 1) the level of the shadow economy, calculated by the method of unprofitable enterprises, 2) the level of the shadow economy, calculated by the electric method. 
Table 5. Matrix paired correlation coefficients tax rate component of financial security and the coefficients of the shadow economy, estimated by different methodological approaches, R (authors' calculations).

\begin{tabular}{|c|c|c|c|c|c|}
\hline- & $\mathbf{y}$ & $\boldsymbol{x}_{\mathbf{1}}$ & $\boldsymbol{x}_{\mathbf{2}}$ & $\boldsymbol{x}_{\mathbf{3}}$ & $\boldsymbol{x}_{\mathbf{4}}$ \\
\hline $\mathrm{y}$ & 1 & $\mathbf{- 0 . 8 9 2}$ & 0.1197 & $\mathbf{- 0 . 7 0 5 1}$ & -0.386 \\
\hline $\boldsymbol{x}_{\mathbf{1}}$ & $\mathbf{- 0 . 8 9 2}$ & 1 & 0.2384 & 0.7109 & 0.2998 \\
\hline $\boldsymbol{x}_{\mathbf{2}}$ & 0.1197 & 0.2384 & 1 & 0.1315 & -0.4018 \\
\hline $\boldsymbol{x}_{\mathbf{3}}$ & $\mathbf{- 0 . 7 0 5 1}$ & 0.7109 & 0.1315 & 1 & 0.5322 \\
\hline $\boldsymbol{x}_{\mathbf{4}}$ & -0.386 & 0.2998 & -0.4018 & 0.5322 & 1 \\
\hline
\end{tabular}

Regression equations impact indicators shadow economy on the tax component of financial security is:

$$
Y=1.3418-0.02556 x_{1}-0.00482 x_{2}
$$

where $x_{1}$ - the level of the shadow economy, calculated by the method of unprofitable enterprises, $x_{2}$ - the level of the shadow economy, calculated by the electric method.

Check for multicollinearity by Fisher's F-criterion:

$$
F_{k}=\left(d_{k k}-1\right) \frac{n-m}{m-1}
$$

where $d_{k k}$ - are diagonal elements of the matrix. The calculated values of the criteria are compared with the tabular ones $v_{1}=n-m, v_{2}=m-1$ at degrees of freedom and level of significance $\alpha$.

$$
\begin{gathered}
v_{1}=9-2=8 ; v_{2}=2-1=2 . F_{\text {tabular }}(8 ; 2)=19.4 \\
F_{1}=(5.149-1) \frac{9-2}{2-1}=16.6
\end{gathered}
$$

Whereas $F_{1} \leq F_{\text {tabular }}$, then the variable is not multicollinear with the others.

$$
F_{2}=(5.235-1) \frac{9-2}{2-1}=16.94
$$

Whereas $F_{2} \leq F_{\text {tabular. }}$, then the variable $x_{1}$ is not multicollinear with the others.

$$
F_{3}=(2.128-1) \frac{9-2}{2-1}=4.51
$$

Whereas $F_{2} \leq F_{\text {tabular. }}$, then the variable $x_{2}$ is not multicollinear with the others.

Estimation of heteroscedasticity based on Spearman's rank correlation coefficient. To test the hypothesis vanishing general Spearman correlation coefficient at the rank competition hypothesis, the critical point is calculated using the formula:

$$
T_{k p}=t(\alpha, k) \cdot \sqrt{\frac{1-p^{2}}{n-2}}
$$

where $n$ - sample size; $p$ - Spearman's sample rank correlation coefficient: $\mathrm{t}(\alpha, k)$ - critical point according to the tables of critical points of Student's distribution, for the level of significance $\alpha$ and degrees of freedom $k=n-2$. 


$$
T_{k p}=2.841 \cdot \sqrt{\frac{1-0.493^{2}}{9-2}}=0.93
$$

According to the Student's table: $t(\alpha / 2, k)=(0,05 / 2 ; 7)=2,841$ Whereas $T_{k p}>$ $p$, then we accept the hypothesis of equality of zero Spearman's rank correlation coefficient. $2,841>0,93$, therefore, the hypothesis of no heteroscedasticity is accepted. Autocorrelation check based on autocorrelation coefficient (if autocorrelation coefficient is $r_{e i}<0,5$, that is, there is reason to believe that autocorrelation is absent).

The standard mistake of the correlation coefficient is calculated by the formula:

$$
S_{e Y}=\frac{1}{\sqrt{n}},
$$

is 0,333 . Since the autocorrelation coefficient of the first order $r 1$ is in the range: -2.969 . $0.333<r_{1}<2.969 \cdot 0.333$, then we can assume that the data do not indicate the presence of first-order autocorrelations. Using the spreadsheet, we obtain:

$$
\begin{gathered}
r_{1} \approx \frac{\sum E_{i} \cdot E_{i-1}}{\sum E_{i}^{2}}=\frac{-0.00946}{0.028}=-0.338 \\
-0.99<r_{1}=-0.338<0.99
\end{gathered}
$$

therefore, the independence property of the residuals is satisfied. Autocorrelation is absent.

Possible economic interpretation of the model parameters: an increase in $x_{1}$ by $1 \%$ leads to a decrease in the level of the tax component of financial security by an average of 0.0256 units.; an increase in $x_{2}$ by $1 \%$ leads to a decrease in $Y$ by an average of 0.00482 units.

In order to expand the possibilities of meaningful analysis of the regression model, private coefficients of elasticity are calculated, which are determined by the formula:

$$
E_{i}=b_{i} \frac{\bar{x}_{i}}{\bar{y}}
$$

The partial coefficient of elasticity shows how many percent on average the resultant characteristic changes when the factor $x_{j}$ increases by $1 \%$ of its average level at a fixed position of other factors of the model.

$$
\begin{aligned}
& E_{1}=-0.0256 \frac{29.222}{0.44}=-1.682 \\
& E_{2}=-0.00482 \frac{31.333}{0.44}=-0.34
\end{aligned}
$$

Partial coefficient of elasticity $|E 1|>1$, and therefore, it significantly affects the performance trait, whereas $|E 2|<1$, accordingly, its effect on the resultant sign $Y$ is insignificant. The statistical significance of the model was verified using the coefficient of determination and Fisher's criterion.

Coefficient of determination $R^{2}=0,806$. To increase the level of objectivity of the assessment, an adjusted coefficient of determination is calculated:

$$
\begin{gathered}
\bar{R}^{2}=1-\left(1-R^{2}\right) \frac{n-1}{n-m-1} \\
\bar{R}^{2}=1-(1-0.8058) \frac{9-1}{9-2-1}=0.741
\end{gathered}
$$

Since the calculated coefficient is close to unity, it can be argued that the formed regression equation explains the behavior of the resultant sign $Y$.

The significance of the regression equation was estimated by testing the hypothesis of equality of the zero coefficient of determination, calculated from the data of the general totality: $R^{2}$ or $b_{1}=b_{2}=\ldots=b_{m}=0$ (hypothesis about the insignificance of the regression equation, calculated from the general totality). 


$$
F=\frac{R^{2}}{1-R^{2}} \frac{n-m-1}{m}=\frac{0.8058}{1-0.8058} \frac{9-2-1}{2}=12.448
$$

According to the Fischer- Snedecor distribution tables, the critical value of the F-criterion (Fcr.) for the level of significance $\alpha=0,05$ and two degrees of freedom $k_{1}=m$ and $k_{2}=$ $n-m-1, k_{1}=2$ and $k_{2}=n-m-1=9-2-1=6$ is $F_{c r .} .(2 ; 6)=5,14$.

Verify the hypothesis of general importance: $H_{0}: R^{2}=0 ; \beta_{1}=\beta_{2}=\ldots=\beta_{m}=$ $0 . H_{1}: R^{2} \neq 0$. Because the actual value $F>F_{c r}$, then the coefficient of determination is statistically significant and the regression equation is statistically reliable (the coefficients $b_{i}$ are jointly significant).

Given the results of correlation and regression analysis, and the method of calculating the index of the shadow economy for the loss by enterprises, whereby it is assumed that all unprofitable enterprises according to official statistics actually are profitable, and their profitability is equal to the profitability of profitable enterprises in the period under analysis [9], we consider it appropriate to analyze the dynamics of unprofitable enterprises through the prism of their possible impact on the level of tax security.

The equation of pairwise regression of the dependence of the level of tax security and the number of unprofitable enterprises has the form: $y=-1,8524 x+1,0288$

Thus, an increase in the share of unprofitable enterprises by 0.1 points could potentially lead to a decrease in the tax security indicator by 0.18524 units.

\section{Formation of regulatory and manage real competence}

The leading functional purpose of the normative-administrative stage of the process of developing methodological approaches to assessing the impact of the shadow economy on financial security is the formation of guidelines for calculating the level of the shadow economy and its impact on financial security of the state in terms of its components: budget, debt currency, monetary, banking, tax, and security of the non-banking sector of the financial market. Taking into account the effects of some of the financial security measures can be developed leveling or reduce the impact of the shadow economy in a particular area of financial market.

\section{Discussion}

To develop measures to de-shadow the financial sector, including fiscal in the financial security system, it is not enough to have an idea of the future financial and economic indicators of society. They should serve as a basis for the formation of a program to strengthen national financial security, and for this it is necessary to have indicators of the impact of the shadow economy on it. Hence, the proposed methodological approaches to calculating the level of the shadow economy and its impact on the financial security of the state in terms of its components play a key role in developing new rules, given today's economic challenges that will successfully combat such a phenomenon as the shadow economy. to develop ways to counteract the shadowing of the economic sector.

It is worth noting that «...in relation to the state and in accordance with American taxation, the cult of self-discipline, order, and organization instilled by the same former religious asceticism, reinforced by a functionally efficient, strict, ruthless state tax service, prevailed in other Western nations. Only in this way can we create a democratic and legal and prosperous state of the modern era with a low level of shadow economy [4]. 


\section{Conclusions}

Thus, the results of the study of the impact of the shadow economy on the level of financial security, confirm the significant impact of the indicator of the level of the shadow economy, calculated using the monetary method on the formation of financial security. At the same time, the in-depth correlation-regression analysis did not confirm the main assumption on which the essence of the method is based, that any increase in cash is evidence of the formation of potential opportunities to increase the level of the shadow economy. Calculations have revealed a significant relationship between the financial security ratio and the dynamics of cash in dollar terms $(r=0,627)$. At the same time, the connection between the features turned out to be direct, which contradicts the working hypothesis about the negative impact of the growth of cash in the economy on the country's financial security.

At the same time, an in-depth analysis of the impact of cash growth on individual indicators of financial security formation showed that only two correlation coefficients were significant, namely: the correlation coefficient of debt security and cash growth $\left(r_{x y}=\right.$ $0,903)$ the correlation coefficient and the security of non-banking financial market and growth of cash $\left(r_{x y}=0,754\right)$. Note that the identified relationship is direct: an increase in cash by $\$ 1$ million US leads to a decrease in monetary security by an average of 0.00321 units, and an increase in cash by $\$ 1$ million US means an increase in the level of debt security by an average of 0.00848 units.

It was also found that two coefficients of the shadow economy level are closely related to the financial security tax indicator: 1) the level of the shadow economy, calculated by the method of unprofitable enterprises, 2) the level of the shadow economy, calculated by the electric method. Augmentation $x_{1}$ (the level of the shadow economy, calculated by the method of unprofitable enterprises) by $1 \%$ leads to a decrease in the level of the tax component of financial security by an average of 0.0256 units; augmentation $x_{2}$ (the level of the shadow economy, calculated by the electric method) by $1 \%$ leads to a decrease in $Y$ by an average of 0.00482 units.

Hence, the approaches to determining the characteristics of the shadow economy on the financial security of the country, which is proposed to be carried out according to the above algorithm, involves determining the level of impact of all components of financial security on the economic environment and taking into account changes in its transformation.

\section{References}

1. V. Melnyk, Administruvannia podatkiv: naukove obgruntuvannia ta orhanizatsiia protsesu (Kondor, K., 2008)

2. N.S. Prokopenko, A.V. Dvorianinov, P.O. Fenenko, Podatkovi mekhanizmy detinizatsii ekonomiky Ukrainy : monohrafiia («Atopol.», Kyiv, 2014)

3. A.S. Poltorak, Finansova bezpeky derzhavy $v$ umovakh hlobalizatsii: teoriia, metodolohiia ta praktyka: monohrafiia (MNAU, Mykolaiv, 2019)

4. V. Andrushchenko, T. Tuchak, Podatkova derzhava (Alerta, K., 2016)

5. S. Holikov, Sutnist podatkovoï bezpeky. Ekonomika ta derzhava 9, 129-132 (2015)

6. O. Baranetska, V. Martyniuk, Nauka moloda 9, 83-87 (2008)

7. M. Vykliuk, Vseukraïnskyy̆ naukovyy̆ vyrobnychyy̆ zhurnal 5, 242-246 (2013)

8. A. Hmyrin, Detinizatsiia ekonomiky: vid tradytsiinykh skhem $i$ deklaratsii do tsyvilizovanoho pidkhodu $i$ rishuchykh dii, https://www.epravda.com.ua/ columns/2020/07/29/663486/ 
9. Metodychni rekomendatsii rozrakhunku rivnia tinovoi ekonomiky, zatverdzheni Nakazom Ministerstva ekonomiky Ukrainy vid 18.02.2009, № 123, https://www.me.gov.ua/LegislativeActs/Detail?lang=uk-UA\&id=4bb297a0-c900-404f8c6f-5f76f18b1503

10. Tendentsii tinovoi ekonomiky $v$ Ukraini $u$ sichni -berezni 2020 roku, https://www.me.gov.ua/Documents/Download?id=699fa73c-084f-431a-949147 ad5ffbaf09

11. H.V. Dolha, O.O. Meleshko, Visnyk Sumskoho natsionalnoho ahrarnoho universytetu. Seriia. Ekonomika i menedzhment 3(85), 44-49 (2020) 